\title{
Biological parameters of fish stock estimation in Cirata Reservoir (West Java, Indonesia): A comparative analysis of bio-economic models
}

\author{
ZUZY ANNA ${ }^{\boldsymbol{\nu}}$, ASEP AGUS HANDAKA SURYANA, INE MAULINA, ACHMAD RIZAL, PURNA HINDAYANI \\ Department of Fisheries Socio-Economics, Faculty of Fisheries and Marine Science, Universitas Padjadjaran. J1. Raya Jatinangor Km 21, Jatinangor- \\ Sumedang, Sumedang 40600, West Java, Indonesia. Tel. +62-22-87701519. Fax.+62-22-87701518. `email: suzyanna18@gmail.com
}

Manuscript received: 1 August 2017. Revision accepted: 25 September 2017.

\begin{abstract}
Anna Z, Handaka AA, Maulina I, Rizal A, Hindayani P. 2017. Biological parameters of fish stock estimation in Cirata Reservoir (West Java, Indonesia): A comparative analysis of bio-economic models. Biodiversitas 18: 1468-1474. Fish resources in reservoirs such as Cirata have a strategic value, especially for the surrounding community in terms of fulfilling the need for nutricious food, subsistence, and economic purposes. Unfortunately, until now there has been no serious attention from the government to develop and manage fish resources in these waters. From time series data it can be seen that there is a decrease in fish production, which is an indication of a decrease of fish stock, which has a negative impact on the wellfare of surrounding commmunity, as well as the sustainability of fish resources and their ecosystems. To meet the food safety and economic needs of the community, a healthy and sustainable fish resource is a must, characterized by sustainable inputs and outputs, so that the stock of fish resources will be maintained. In order to fulfill this need, a basic understanding of the biological and economic conditions of the dynamics of fish resources in these waters as a basis for sustainable management is needed. Research was conducted to calculate the biological parameters of fish resources through Fox, CYP, Walters Hilborn and Schnute algorithms, using quarterly catch and effort data from 2011 to 2015 , collected from secondary and cross checking data. Furthermore, using price and cost data series, adjusted by consumer price index, the variable of input, output and economic rent of sustainable, optimal and open access management regimes were analyzed. The results of the study indicate that the most statistically appropriate model for estimating biological parameters in Cirata are the Fox and CYP models, and fisheries management using the optimal regime provides the most efficient results, where fewer inputs will result in the maximum profit. The research suggests the need for immediate enforcement of management rules based on sustainable management regimes through input or output restrictions on capture fisheries in Cirata Reservoirs.
\end{abstract}

Keywords: Biological parameters, fish stock, bio-economic models, sustainable and optimal

\section{INTRODUCTION}

Fish resources in reservoir waters are resources that contribute to the food security and the economy of the surrounding community. Capture fishery is one of the important activities related to fish resources that contributes the most to the surrounding community compared to capital-intensive cultivation activities. Capture fisheries actvities both subsistence, commercial, and recreational, also have a major impact on the growth dynamics, carrying capacity, availability, and sustainability of fish stocks in these waters, apart from the environmental conditions of the waters, and other external impacts. The sustainability of fish resources in these waters is not only of great significance to the local people who depend on these resources but is also important as one of the biotic configurations for the sustainability of the reservoir ecosystem (Angeler et al. 2005, 2002a, b, 2003 (see References); Zimmer et al. 2003; Bell and Kalff. 2001). Fish can be the counterweight to the aquatic system through its various functions in nature in the food web systems, even further into microclimate balancing and preventing the spread of infectious diseases due to the development of larvae of insects such as mosquitoes in waters, and controlling the development of aquatic weeds. (Van Dyke et al. 1984; Pauly et al. 1998; Sutton et al.
2014; Edmunds 2015; Sullivan et al. 2015).

Thus, the availability of an adequate fish stock will be very beneficial for the sustainability of the dam ecosystem. The exploitative behavior that is improper according to the rules, excessive, and tends to be destructive will greatly affect the availability of fish stocks in the waters. Utilization of water resources as a fish habitat that is also not right such as pollutive behavior, sediment accumulation and flood problems both from activities in the waters themselves and from the mainland that deliberately discharged into the waters will also greatly affect the reservoir's demands, riverine ecosystem, habitat and fish stocks in the waters (Saha and Setegn 2015a 2015b (see References); Grigg 2016; Gorenflo and Warner 2016; Xu et al. 2014; Chen and Tsai 2017 - not in References). Cirata Reservoir is an example of a water body that suffered decreasing fish stocks, characterized by the decreasing number of catches from year to year as a result of various production activities such as capture fisheries and cultivation, as well as non-production activities such as the disposal of liquid and solid waste into the waters (Anna, 2016). There is a concern that this condition would cause the depletion of fish resources so that they become scarce and, more importantly, would cause extinction of important economic types of fish species, and even endemic fish that characterize the waters here. 
The information on the biological parameter conditions of the fish stocks becomes important for stakeholders associated with reservoir management, as a basis for policy-making for the general management of integrated reservoirs and in particular the utilization of fish resources in the region. The data of the biological parameter values until now have not existed for this reservoir, especially for the total production and effort available those obtained from various bio-economic analyzes simultaneously. This research will calculate the value of biological parameters such as the intrinsic growth as well as the ability of environmental carrying capacity and capability of catching fish resources in Cirata Reservoir waters by using various models of analysis estimation of fish biology parameters. Those biological paramaters could be very usefull for further analysis of sustainable and optimal management of fisheries in the reservoir.

\section{MATERIALS AND METHODS}

This research was conducted in Cirata Reservoir using the data series of total capture fishery input and output every quarter from 2010 to 2016. The economic data of price and nominal average costs were obtained from cross section and adjusted to inflation to get real price per year. This economic data was obtained from interviews of 100 fishermen using various types of fishing gear used in these waters, namely gillnet, cast net, and hand line. Due to the difference in capability of the fishing gears, the standardization was done using gillnet as the base calculation, using technique developed by King (1995), as follows:

$$
E_{j t}=j_{j t} D_{j t}
$$

and

$$
j_{j t}=\frac{u_{j t}}{u_{s t}}
$$

Where,

$E_{j t}=$ Effort from gear $\mathrm{j}$ at $\mathrm{t}$ standardized

$D_{j t}=$ Fishing days) of gear $\mathrm{j}$ at $\mathrm{t}$ period

$J_{j t}=$ Fishing power of gear $\mathrm{j}$ at $\mathrm{t}$ period

$u_{j t}=$ Catch per unit effort (CPUE) of gear $\mathrm{j}$ at $\mathrm{t}$ period

$u_{s t}=$ Catch per unit effort (CPUE) of gear based for standardized

The analysis method used to observe the dynamics of fish in Cirata is the bio-economic method by using estimation of production surplus model. The surplus production concept is a basic concept of the fishery knowledge based on the idea that the increase of fish population will be obtained from the small fish that produced every year, whereas the decrease of the mentioned population was due to the mortality, either because of the natural factor or by the human exploitation. This model needs the data catch (yield) and effort, two kinds of data that were collected and published in the fishery statistics. While in the dynamic pool, the parameters of the fish population was sorted and counted one by one, so the model is often called the analytical model. Ideally, the analysis should be done for every single species, but in the study case, the multiple species is treated as single species, due to the nature of the data. The use of this surplus production model has been widely used in various models of multi-species fisheries estimation and multispecies aggregate or lumped model (Mueter and Megrey 2006; Fogarty et al. 2012).

In the model of production surplus, the dynamics of biomass are described as the difference between natural production and mortality as illustrated in the following equation:

Biomas in $\mathrm{t}+1=$ biomas in $\mathrm{t}+$ production - natural mortality

The above equation states that if the production exceeds the natural mortality, then the biomass will increase, otherwise if natural mortality is higher than production, then the biomass will decrease. The term surplus of production itself illustrates the difference or deviation between natural production and natural mortality. Furthermore, Hilborn and Walters (1992) argue that the production surplus represents an increase in the number of fish stocks in the absence of catching activity or in other words, the amount that can be caught if the biomass is maintained at a fixed rate. In the case of the introduction of catching, logistic model analysis is used to analyzed production function.

In this study, the production surplus model to be used is the equilibrium state model and parameter estimation model from Fox (1970), Clark et al. (1992), Walters and Hilborn (1976) and Schnute (1977) and the production surplus model to estimate the value of biological parameters of fish resources in Cirata Reservoir, is a logistic model developed that assumes that population growth is consistent with the proportion of the initial population, called the growth rate of intrinsic fish or $r$. While the rate of change of fish stock is formulated as:

$$
\frac{d x}{d t}=r x\left(1-\frac{x}{K}\right)
$$

Where: $\mathrm{x}$ is the fish stock or the biomass, $\mathrm{K}$ is carrying capacity, and $\mathrm{r}$ is the intrinsic fish growth rate. By introducing the capture fisheries (h) to this stock growth function that is the stock function as well, catchability coefficient (q), and input (E), or:

$$
h=q \times E
$$

Thus, in a long term, the fish resources equilibrium would be:

$$
q x E=r x\left(1-\frac{x}{K}\right)
$$

Thus, the correlation between the catch per unit effort with effort can be obtained as follows:

$$
\frac{h}{E}=q K\left(1-\frac{q}{r} E\right)
$$


Table 1. Formula for Model Parameter Estimations

\begin{tabular}{ll}
\hline $\begin{array}{c}\text { Model parameter } \\
\text { estimations }\end{array}$ & \multicolumn{1}{c}{ Formula } \\
\hline Fox & $(\mathrm{Ut}+1-\mathrm{Ut}-1) / 2 \mathrm{Ut}=\mathrm{rLn} \quad(\mathrm{qK})-\mathrm{rln} \quad(\mathrm{Ut})-\mathrm{qLn}$ \\
& $(\mathrm{Et})$ \\
CYP & $\mathrm{Ln} \mathrm{Ut}+1=\mathrm{a}+\mathrm{b} \mathrm{Ln} \mathrm{Ut}+\mathrm{c}(\mathrm{Et}+\mathrm{Et}+1)$ \\
Walters - Hilborn & $((\mathrm{Ut}+1 / \mathrm{Ut})-1)=\mathrm{r}-\mathrm{r} / \mathrm{Kq}(\mathrm{Ut})-\mathrm{q}(\mathrm{Et})$ \\
Schnute & $\begin{array}{l}\ln (\mathrm{Ut}+1 / \mathrm{Ut})=\mathrm{r}-\mathrm{r} / \mathrm{Kq}(\mathrm{Ut}+1+\mathrm{Ut} / 2)-\mathrm{q} \\
\end{array}$ \\
\hline
\end{tabular}

From the above equation, the parameter estimations of $\mathrm{r}, \mathrm{K}$ and $\mathrm{q}$ for the equation yield-effort model involve nonlinear technique. By using $U_{t}=h_{t} / E_{t}$ formula, (CPUE or catch per unit effort), equation could be transformed into a linear equation so that ordinary least square regression method can be used to estimate the biological parameters of the above functions. Fox, CYP, Walters Hilborn and Schnute algorithms are used to measure the biological parameters of fish through the following equation:

The Fox Model (Fox 1975) is a development of production surplus model for parameter estimation using equilibrium models based on Schaefer model analysis, in a linear-non-linear (natural logarithmic) form. The Fox model has several different characters than the GrahamSchaefer model. The difference is that the Fox model states that biomass growth follows the Gompertz growth model, and the Catch Per Unit Effort (CPUE $_{t}$ ) (what is CPUEt?) decline in the catch effort follows a negative exponential pattern, which makes more sense than the linear regression pattern. While the CYP model uses log model to estimate biological parameters, in a discrete form of logarithmic in natural logarithmic, which is a quite simple but logic in the natural system. In the Walters-Hilborn estimation model (Walters and Hilborn 1976), the production surplus model developed is the difference model, the discrete version. While on the Schnute model, which is also a modification of the Schaefer model, is using non linear analysis, log and also reciprocal. The Schnute model (Schnute 1977) presents another version of the dynamic, discrete in time, and deterministic model of production surplus from the Graham-Schaefer way. On the other hand, it provides a dynamic, stochastic time model, and is specific to the surplus production model as opposed to static, deterministic, and continuous models of other GrahamSchaefer models. The Schnute model is seen as a modification of the Schaefer model in discrete form. The parameters estimated from those models are intrinsic growth rate $(r)$ refer to how much a population can grow between successive time periods, which often estimated with production models and plays an important role in evaluating the sustainability of different harvest levels and the capacity to recover after depletion; Carrying capacity $(K)$ refer to the number of biomass of a particular species that the resources in the habitat can support (Myers et al. 2001); and Catchability coefficient $(q)$, refer to fish caught per fish available per effort unit and per time unit. Catchability is also called gear efficiency (Hilborn and Walters 1992) or sometimes fishing power, and is strongly related to gear selectivity.
The use of these models is comparable, to see how the statistics perform and also to determine the approximate estimates of the biological parameter values. The data Regression analysis is done using Stata SE 12, and Minitabs. The calculation of the sustainable and optimal production and efforts was done using MAPLE 17.0. software and Microsoft Excell.

\section{RESULTS AND DISCUSSION}

\section{Results}

Cirata Reservoir include 18 species of fish from eight families, namely Cyprinidae, Bagridae, Eleotridae, Cichlidae, Pangasidae, Ophiocephalidae, Chanidae and Characidae (Jubaedah, 2004). While the abundance of fish based on the study of Wahyuni et al. (2014) (something not quite right in the start of this sentence) in observation of February, dominated by Hampala macrolepidota (40,74\%) and Oreochromis niloticus (18,67\%), March was dominated by Oxyeleotris marmorata $(89,65 \%)$ and Oreochromis niloticus (19,89\%), April was dominated by Chanos chanos $(62.79 \%)$ and Oreochromis niloticus (20.48\%), May was dominated by Hampala macrolepidota $(14.81 \%)$ and Oreochromis niloticus (12.65\%), June was dominated by Aequidens pulcher (36.47\%) and Amphilopus citrinellus (30.18\%), July was dominated by Mystus nigriceps (80.43\%) and Amphilopus citrinellus (44.33\%).

The data used in this study is quarterly, because that is what is available. In each quarter only production data varies, while effort is relatively fixed in every quarter of every year, and only changes in the next year. This is because data collection is only done once? per year. So the quarterly effort is assumed to be the same every year. From the quarterly production, Cirata fisheries shows significantly decrease from year to year. The average effort trend is increasing from year to year, with the total effort at the end of 2016 as much as 60984.94 trips, which comes from three types of fishing gear such as Handline, Castnet and Gillnet. The average trip of the fishing gear is - (what does this mean? once?) twice a day with a day of catching fish on average 25 days per month. Cirata fisheries is also characterized by a relatively low CPUE value, and relatively decreased throughout the year. By the end of 2016, the value of CPUE is $2 \mathrm{Kg}$ per trip, as shown in Table 2.

The results of statistical performance analysis of the development of Fox model, Walters Hilborn, Schnute and CYP can be seen in the table 3 (do you mean Table 3? Indicate which table). It appears that the Fox model which specificly use Schaefer model for regression to get constant and $E_{t}$ value, has a fairly good statistical performance, where CYP has the highest $\mathrm{R}^{2}$ value of $81.4 \%$, which means that the dependent variable can be explained by the explanatory variable of $81.4 \%$ and the rest by other variables outside the model. Furthermore, the $\mathrm{R}^{2}$ value for the Fox model is 25.6, while other models have low $\mathrm{R}^{2}$ values, even $0.0 \%$ for the Schnute model. Although the actual value of $\mathrm{R}^{2}$ in the regression analysis of the bioeconomic model which purpose is to obtain the parameter 
Table 2. Cacht Per Unit Effort (CPUE)

\begin{tabular}{ccccc}
\hline Year & Quarterly & $\begin{array}{c}\text { Total } \\
\text { standard } \\
\text { effort (trip) }\end{array}$ & $\begin{array}{c}\text { Actual } \\
\text { production } \\
\text { (ton) }\end{array}$ & CPUE \\
\hline 2011 & 1 & 50215,87 & 328,55 & 0,007 \\
& 2 & 50215,87 & 341,79 & 0,007 \\
& 3 & 50215,87 & 335,04 & 0,007 \\
2012 & 4 & 50215,87 & 337,29 & 0,007 \\
& 5 & 53476,47 & 319,16 & 0,006 \\
& 6 & 53476,47 & 315,19 & 0,006 \\
& 7 & 53476,47 & 315,64 & 0,006 \\
2013 & 8 & 53476,47 & 295,39 & 0,006 \\
& 9 & 44176,47 & 224,32 & 0,005 \\
& 10 & 44176,47 & 147,32 & 0,003 \\
& 11 & 44176,47 & 128,32 & 0,003 \\
2014 & 12 & 44176,47 & 165,32 & 0,004 \\
& 13 & 57661,22 & 243,78 & 0,004 \\
& 14 & 57661,22 & 166,78 & 0,003 \\
& 15 & 57661,22 & 147,78 & 0,003 \\
& 16 & 57661,22 & 184,78 & 0,003 \\
& 17 & 58840,93 & 129,44 & 0,002 \\
& 18 & 58840,93 & 117,44 & 0,002 \\
& 19 & 58840,93 & 166,44 & 0,003 \\
& 20 & 58840,93 & 170,44 & 0,003 \\
& 21 & 60984,94 & 135,54 & 0,002 \\
& 22 & 60984,94 & 106,27 & 0,002 \\
& 23 & 60984,94 & 131,77 & 0,002 \\
& 24 & 60984,94 & 129,83 & 0,002 \\
\hline
\end{tabular}

value is not a very important issue, but the value of $\mathrm{R}^{2}$ is expected not to be too low (below 25\%) (Anna 2003; see reference in dissertation). When viewed from the $\mathrm{P}$ value, only Fox and CYP variables that have significant value, with $90 \%$ and $95 \%$ confidence levels. To determine the effects of all variables on $\mathrm{F}$ probability, as can be seen from the table, $F$ probability has a value of less than 0.05 or $5 \%$ for Fox and CYP Models, meaning that all variables of independent variables jointly affect the dependent variables. While for Walters Hilborn and Schnute have a value of more than 0.5 both models, meaning that all variables jointly do not affect the dependent variables. For the Durbin-Watson statistic (DW), all model's values are in the range of $-2<\mathrm{DW}<2$, indicating that there is no interference autocorrelation on all models. The Varian Inflation Factor (VIF) values below 10 indicates that there are no multi-collinearity between variables. Look into the yield effort model resulting from the regression analysis, can be seen that the model that according to the original formulation model and following the right sign for coefficient are Fox. Walters Hilborn and CYP model, while Schnute does not have an appropriate coefficient sign. It means that Schnute model couuld not be consider to be the good model for the Cirata's Fisheries parameters estimation. From the regression analysis, it appears that the Fox model and the CYP Model have the best statistical performance.

By using various variations of the production surplus model, the estimation of biological parameters for fisheries in Cirata Reservoir is shown in the following table. The result shows that, if (meaning not clear here) it refers to the significance of the model, the Fox and CYP parameter is a relatively more suitable parameter that can be used in further analysis for fisheries sustainability in Cirata Reservoir. In addition, the value of biological parameters especially carrying capacity in the Fox (Schaefer regression) model close to reality. Referred to the amount of production per quarter, the average production is only around 100-300 tons.

For further analysis, finding sustainable yield and also optimal yield can be only done by using Fox and CYP models that have the best fits compared with other models. Optimization analysis is conducted on various management instruments, namely Maximum Economic Yields, Maximum Sustainable Yield, Open Access, and Optimal dynamic. In the optimal dynamic model, elasticity analysis is performed by using various discount rate values and the results for the Fox model can be shown in Table 5. The highest biomass will be obtained if the fishery is managed by using sole owner or Maximum Economic Yield (MEY), with biomass 459 Ton, with the most efficient effort of 33.309 trips. However, if the goal is to get the highest profit, the recommended instrument used is optimal dynamic with $5 \%$ discount rate. Currently, this discount rate is the lowest bank interest rate (BI Rate 2010-2016). Open access management are the lowest production value, the highest effort, the lowest biomass value, and zero profit value, so it is not a sugested instrument to be implemented. Thus, the management with a Maximum Economic Yields (MEY) instrument and also an optimal dynamic can be suggested for Cirata's fishery, so that fish resources can be optimal and sustainable.

\section{Discussion}

The results show that the most statistically appropriate model for estimating biological parameters in Cirata are the Fox and CYP models. This is in line with previous studies related to fish resources in tropical regions such as Indonesia with fish resources in multi-species waters and multi-gears, the use of Fox and CYP models is considered the most appropriate compared to using other models such as Walters Hilborn and Schnute (Pasisingi 2011; Sari 2012; Tinungki et al. 2004; Tinungki 2005; Triharyuni et al. 2014; Kekenusa et al. 2014). The two best model are also consider to be the appropriate model for multispecies aggregate or lumped model (Mueter and Megrey 2006; Fogarty et al. 2012).

The Fox model (Fox 1997) is basically a model that has its growth characteristics following the Gompertz model. In this model, the CPUE correlation and the production or catch results are in accordance to negative exponential pattern, meaning it makes more sense when compared to the linear regression model. In addition the Fox model also uses some logical assumptions such as that the population as a number of fish populations will not be extinct, and the relation between effort and catch is exponential with an asymmetric curve. While, the CYP model is a discrete form of logarithmic in natural logarithmic which is also simple but logical, it becomes the model that generates the best fit on biological parameter estimations of fish resources in Indonesia (Anna 2003; Fauzi and Anna 2005; Anna 2016). Thus, the parameter estimation model of Fox and CYP is 
suggested to be applied in Cirata's fish stock assessment. The results of the analysis using both models show that the biological parameter values randomly ranged from 0.18 -
$0.12 ; \mathrm{K}$ between 815 tons to 4144 tons and $\mathrm{q}$ between 0.000016 up to 0.000008 , relatively logical value if looking from the actual production conditions.

Table 3. Statistic performance for all models

\begin{tabular}{|c|c|c|c|c|c|c|c|c|c|c|c|c|}
\hline \multirow[b]{3}{*}{ Variable } & \multicolumn{12}{|c|}{ Model } \\
\hline & \multicolumn{3}{|c|}{ Fox (Schaefer) } & \multicolumn{3}{|c|}{ Walters Hilborn } & \multicolumn{3}{|c|}{ Schnute } & \multicolumn{3}{|c|}{ CYP } \\
\hline & ن⿺辶大 & 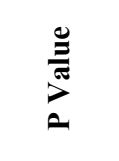 & $\stackrel{1}{>}$ & ن⿺辶大 & 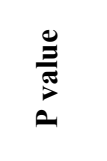 & 巫 & نे & 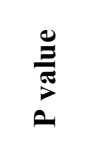 & 少 & نे & 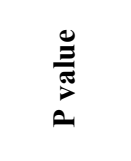 & 壬 \\
\hline Constant & $0.01299 * *$ & 0.0000 & & 0.4195 & 0.438 & & -0.094 & 0.88 & & $0.5533^{*}$ & 0.0327 & \\
\hline Et & $-0.00000017 * *$ & 0.007 & 1,000 & -0.0000058 & 0.509 & 1,357 & & & & & & \\
\hline Ut-1 & & & & -33.8 & 0.237 & 1.357 & & & & & & \\
\hline $\mathrm{Et}+\mathrm{Et}+1$ & & & & & & & & & & $0.00000386^{* *}$ & 0.0044 & 1.583 \\
\hline Ln Ut & & & & & & & & & & $0.8352 * *$ & 0.000 & 1.583 \\
\hline$(E t+E t+1) / 2$ & & & & & & & 0.00000072 & 0.943 & 1.465 & & & \\
\hline$(\mathrm{Ut}+\mathrm{Ut}+1) / 2$ & & & & & & & 1.65 & 0.959 & 1.465 & & & \\
\hline $\mathrm{R}^{2}$ & \multicolumn{3}{|c|}{29.1} & \multicolumn{3}{|c|}{6.9} & \multicolumn{3}{|c|}{0.00} & \multicolumn{3}{|c|}{81.4} \\
\hline Adj $R^{2}$ & \multicolumn{3}{|c|}{25.9} & \multicolumn{3}{|c|}{0.00} & \multicolumn{3}{|c|}{0.00} & \multicolumn{3}{|c|}{79.6} \\
\hline F Statistik & \multirow{2}{*}{\multicolumn{3}{|c|}{$\begin{array}{c}9.03 \\
0.007\end{array}$}} & \multicolumn{3}{|c|}{0.75} & \multicolumn{3}{|c|}{0.00} & \multicolumn{3}{|c|}{43.9} \\
\hline Prob F Stat & & & & \multirow{2}{*}{\multicolumn{3}{|c|}{0.49}} & \multicolumn{3}{|c|}{0.97} & \multicolumn{3}{|c|}{0.000} \\
\hline Durbin Watson & \multicolumn{3}{|c|}{0.736} & & & & \multirow{2}{*}{\multicolumn{3}{|c|}{$\begin{array}{l}\mathrm{Ln} \mathrm{Ut}+1 / \mathrm{Ut}=-0.094+1.6 \\
(\mathrm{Ut}+\mathrm{Ut}+1) / 2+0.000001 \\
(\mathrm{Et}+\mathrm{Et}+1) / 2\end{array}$}} & \multicolumn{3}{|c|}{1.934} \\
\hline Formulation & \multicolumn{3}{|c|}{$\mathrm{Ut}=0.0130-0.000000 \mathrm{Et}$} & \multicolumn{3}{|c|}{$\begin{array}{l}(\mathrm{Ut}+1 / \mathrm{Ut})-1=0.420-33.8 \\
\mathrm{Ut}-1-0.000006 \mathrm{Et}\end{array}$} & & & & $\begin{array}{l}\text { Ln CPUEt+1 } \\
\text { Ln CPUEt + } \\
\text { Et+Et+1 }\end{array}$ & $\begin{array}{l}=0.553+ \\
0.000004\end{array}$ & +0.835 \\
\hline
\end{tabular}

Table 4. Biological Parameterization of all Models

\begin{tabular}{lllll}
\hline Parameters & Fox & Walters Hilborn & Schnute & CYP \\
\hline Intrinsic Growth (r) & 1.217 & 0.420 & 0.094 & 0.180 \\
Carrying Capacity (K) Ton & 815.00 & 2139.87 & 79948.991 & 4144.41 \\
Catchability Coefficient (q) & 0.000016 & 0.000006 & 0.0000007 & 0.000008 \\
\hline
\end{tabular}

Table 5. Fox model optimization analysis

\begin{tabular}{lrrrrrrr}
\hline Variable & \multicolumn{1}{c}{$\begin{array}{c}\text { Sole } \\
\text { owner/MEY }\end{array}$} & Open access/OA & MSY & $\begin{array}{c}\text { Optimal } \\
\text { dynamic } \\
(\mathbf{i}=\mathbf{5})\end{array}$ & $\begin{array}{c}\text { Optimal } \\
\text { dynamic } \\
(\mathbf{i}=\mathbf{6})\end{array}$ & $\begin{array}{c}\text { Optimal } \\
\text { dynamic } \\
(\mathbf{i}=\mathbf{7})\end{array}$ & $\begin{array}{c}\text { Optimal } \\
\text { dynamic } \\
(\mathbf{i}=\mathbf{8})\end{array}$ \\
\hline $\mathrm{x}$ (ton) & 459.96 & 104.52 & 407.70 & 4447.44 & 445.03 & 442.65 & 440.31 \\
$\mathrm{~h}^{*}$ (ton) & 244.07 & 110.92 & 248.15 & 245.79 & 246.07 & 246.32 & 246.56 \\
$\mathrm{E}^{*}$ (ton) & 33308.64 & 66617.27 & 38205.88 & 34482.26 & 34707.95 & 34930.76 & 35150.75 \\
$\mu$ (Profit) & 2548.67 & 0.00 & 2493.58 & 52172.62 & 43662.68 & 37580.27 & 33015.14 \\
\hline
\end{tabular}

Table 6. CYP model optimization analysis

\begin{tabular}{|c|c|c|c|c|c|c|c|}
\hline Variable & Sole owner/MEY & $\begin{array}{c}\text { Open } \\
\text { access } / O A\end{array}$ & MSY & $\begin{array}{c}\text { Optimal } \\
\text { dynamic } \\
(\mathrm{i}=5)\end{array}$ & $\begin{array}{c}\text { Optimal } \\
\text { dynamic } \\
(\mathrm{i}=6)\end{array}$ & $\begin{array}{c}\text { Optimal } \\
\text { dynamic } \\
(i=7)\end{array}$ & $\begin{array}{c}\text { Optimal } \\
\text { dynamic } \\
(\mathrm{i}=8)\end{array}$ \\
\hline $\mathrm{x}$ (ton) & 2167.82 & 191.23 & 2072.20 & 87.25 & 1577.03 & 1487.53 & 1401.04 \\
\hline $\mathrm{h}^{*}$ (ton) & 185.69 & 32.76 & 186.08 & 5.85 & 282.77 & 265.07 & -515.60 \\
\hline$E^{*}$ (ton) & 10191.79 & 20383.57 & 10684.79 & 7973.25 & 21334.59 & 21202.71 & -43788.62 \\
\hline$\mu$ (Profit) & 2370.28 & 0.00 & 2364.74 & -1999.20 & 59701.17 & 47797.64 & -80991.89 \\
\hline
\end{tabular}


Optimization analysis on both Fox and CYP models shows that the management instrument that produces the most efficient condition is the Maximum Economic Yield (MEY). This management regime shows the highest biomass value, with the most relatively conservative effort, but high rent, although not as high as the dynamic management. This can be explained because the MEY is achieved in a condition where the marginal revenue curve cuts the marginal cost curve (Fauzi 2004; Fauzi and Anna 2005; Anderson 2010), so that the profit will be maximized. While in the open access condition, total revenue equals to the total cost, so the profit earned becomes zero. Thus, the management of MEY-based instruments is strongly recommended to be applied in Cirata Reservoir.

This MEY-based management can be operationally operated through input or output restrictions, depending on the socio-economic conditions of the community. If the community is still in need of fish resources as food and is subsistent, it is better to limit or impose quota (what is this?) to the output, by dividing the optimal production value in the MEY regime by the number of fleets or fishing gears available proportionately. While if the condition of the society is more prosperous and more commercial fishing activities occurs, then input restrictions can be suggested (Anna 2016). This is due to the nature of Indonesian fisheries and fishers characteristic, where input restriction will impacted to the poors and increase the number of unemployee, which often leads to potential conflict and social instability. The input limitation/quota can be done by referring to the optimum number of inputs (trip) in MEY, and adjusting to the number of available fleets, so the number of fishing gear or fleet that should be limited can be found, for sustainable fish resources.

However, this study still needs further research focusing on species, to determine the biological parameter values of each fish species present in this body of water using various models. Understanding the the biological parameter dynamics of any fish species present in these reservoir waters will be highly beneficial for sustainable management. In addition, there should also be an optimal measurement of input and output for each species of fish in the Cirata Reservoir, so that the management can be directly conducted on each species of fish to obtain the optimal and sustainable conditions.

\section{ACKNOWLEDGEMENTS}

The authors would like to thank to the directorate General of Higher Education, Ministry of Research and Technology and Higher education for Research Grant PUPT Scheme in 2017.

\section{REFERENCES}

Anderson LG, Seijo JC. 2010. Bioeconomics of Fisheries Management John Willey and Sons, New York, USA.
Angeler DG, Alvarez-Cobelas M, Sánchez-Carrillo S, Rodrigo MA. 2002a. Assessment of exotic fish impacts on water quality and zooplankton in a degraded semiarid floodplain wetland. Aquat Sci 64: 76-86.

Angeler DG, Rodrigo MA, Sánchez-Carrillo S, Alvarez-Cobelas M. 2002b. Effects of hydrologically confined fish on bacterioplankton and autotrophic picoplankton in a semiarid marsh. Aqua Micro Ecol 29: 307-312.

Angeler DG, Sánchez-Carrillo S, Alvarez-Cobelas M, Cirujano S, Medina L. 2003. Exotic crayfish activity and its effects on water quality: preliminary implications for the alternative stable equilibria in Mediterranean wetlands. Journal of Mediterranean Ecology 4: 13-21.

Angeler DG, Sánchez-Carrillo S, Rodrigo MA et al. 2005. On the importance of water depth, macrophytes and fish in wetland picocyanobacteria regulation. Hydrobiologia 549 (1): 23. DOI:10.1007/s10750-005-1700-5

Anna Z. 2003. Dinamic Embedded Model Economic Interaction FisheriesPollution. [Dissertation]. Bogor Agricultural University, Bogor. [Indonesian].

Anna Z. 2016. Cirata's fisheries sustainable management: a bio-economic modelling approach. Marine and Fisheries Socio-Economi Journal 11 (2): 161-172 . [Indonesian]

Anurani P, Andreas L, Wendel K, F. Chris, Peter D, John G, Tom J. 2015. Trophic dynamics of several fish species in lakes of a climatically sensitive region, the Hudson Bay Lowlands. Polar Biol 38: 651-664.

Bell T, Kalff J. 2001. The contribution of picophytoplankton in marine and freshwater systems of different trophic status and depth. Limnology and Oceanography 46: 1243-1248.

Clarke RP, Yoshimoto SS, Pooley SG. 1992. A bioeconomic analysis of the Northwestern Hawaiian islands lobster fishery. Mar Resour Econ 7: $115-140$.

Edmunds NB. 2015. The Effect of Food Web Structure on Teleost Fish Brain Size and Morphology in an Aquatic Ecosystem. [Thesis]. University of Guelph, Ontario.

Fauzi A, Anna Z. 2005. Modelling of Fisheries and Marine Resources for Policy Analysis. Gramedia Pustaka Utama, Jakarta. [Indonesian]

Fauzi A. 2004. Resource and Environmental Economics: Theory and Application [Indonesian]. Gramedia Pustaka, Jakarta.

Fogarty MJ, Overholtz WJ, Link JS. 2012. Aggregate surplus production models for demersal fishery resources of the Gulf of Maine. Mar Ecol Prog Ser 459: 247-258.

Fox W. 1970. Exponential surplus-yield model for optimizing exploited fish populations. Trans Amer Fish Soc 99: 80-88.

Gorenflo L, Warner DB. 2016. Integrating biodiversity conservation and water development: In search of long-term solutions. Wiley Interdiscip Rev Water 3: 301-311.

Grigg NS. 2016. Models, Data, and Monitoring in IWRM. In: Integrated Water Resource Management. Springer, London.

Hayes CG. 2007. Investigating Single and Multiple Species Fisheries Management: Stock Status Evaluation of Hammerhead (Sphyrna spp.) Sharks in The Western North Atlantic Ocean and Gulf of Mexico. [Thesis]. Virginia Polytechnic Institute and State University, Virginia.

Hilborn R, Walters C. 1992. Quantitative Fisheries Stock Assessment Choice, Dynamic and Uncertainty. Chapman and Hall, New York.

Jubaedah I. 2004. Food Distribution of Hampal Fish (Hampala macrolepidota C.V) in Cirata Reservoir, West Java. [Thesis]. Institut Pertanian Bogor, Bogor. [Indonesian]

Kekenusa JS, Rondonuwu SB, Paendong MS, Weku WCD. 2014. Status determination of utilization and scenarios mackerel tuna (auxis rochei) management in the district of Siau-Tagulandang-Biaro, North Sulawesi. Journal Ilmiah Sains 14 (2): 136-145. [Indonesian]

King M. 1995. Fisheries Biology, Assessment and Management. Fishing News Book, Great Britain.

King RS, Tsai CM. 2017. Development of an evaluation system for sustaining reservoir functions - a case study of Shiwen Reservoir in Taiwan. Sustainability 9 (8): p.1387.

Mueter J, Megrey BA. 2006. Using multi-species surplus production models to estimate ecosystem-level maximum sustainable yields. Franz Fish Res 81: 189-201.

Myers RA, MacKenzie BR, Bowen KG, Barrowman NJ. 2001. What is the carrying capacity for fish in the ocean? A meta-analysis of population dynamics of North Atlantic cod. Canadian J Fish Aquat Sci 58: 1464-1476. 
Pasisingi N. 2011. Surplus Production Model for Crab Resource Management (Portunus pelagicus) in Banten Bay, Serang District, Banten Province. [Thesis]. Institut Pertanian Bogor, Bogor. [Indonesian]

Pauly DV, Christensen J, Dalsgaard R, Froese, F. Torres Jr. 1998. Fishing down marine food webs. Science 279: 860-863.

Saha AK, Setegn SG. 2015a. Ecohydrology for sustainability of IWRM: A tropical/subtropical perspective. In: Sustainability of Integrated Water Resources Management. Springer, Switerzerland.

Saha AK, Setegn SG. 2015b. Ecohydrology: Understanding and maintaining ecosystem services for IWRM. In :Sustainability of Integrated Water Resources Management. Springer, Switerzerland.

Sari FN. 2012. Analysis of Bioeconomics for Utilizing Crab Resource (Portunus pelagicus) In Banten Bay, Serang, Banten. [Thesis]. Institut Pertanian Bogor, Bogor. [Indonesian]

Schnute J. 1977. Improved estimates from the Schaefer production model: theoretical consideration. J Fish Res Board Canada 34: 583-603.

Sullivan SMP, Hossler K, Cianfrani CM. 2015. Ecosystem structure emerges as a strong determinant of food-chain length in linked stream-riparian ecosystems. Ecosystems 18 (8): 1356-1372.

Sutton DL, Vandiver VV, Hill JE. 2014. Grass carp: a fish for biological management of hydrilla and other aquatic weeds in Florida. UF/IFAS Extension Bull 867: https://edis.ifas.ufl.edu/pdffiles/FA/FA04300.pdf

Tinungki GM, Boer M, Monintja DR, Widodo J, Fauzi A. 2004. Model surshing: Model hybrid between surplus production and cushing model in fish stock estimation (Case study; Lemuru in Bali strait) [Indonesian]. Jurnal Ilmu-ilmu Perairan dan Perikanan Indonesia 11 (2): $135-138$.

Tinungki GM. 2005. Evaluation of Production Model in Expecting Maximum Sustainable Yield to Support Lemuru Fisheries Management Policy in Bali Strait. [Dissertation]. Institut Pertanian Bogor, Bogor. [Indonesian]

Triharyuni S, Hartati ST, Nugroho D. 2014. The evaluation of scad fish (Decapterus spp.) potential at WPP 712- Java Ocean. Jurnal Penelitian Perikanan Indonesia 20 (3):143-152. [Indonesian]

Van Dyke JM, AJ Leslie Jr, LE Nall. 1984. The effects of the grass carp on the aquatic macrophytes of four Florida lakes. J Aquat Plant Manag 22: 87-95.

Wahyuni S, Sulistiono, Affandi R. 2014. Spatial and temporal distribution of fishes in Cirata Reservoir, West Java. Bumi Lestari 14 (1): 74 - 84. [Indonesian]

Walters C, R. Hilborn. 1976. Adaptive control of fishing systems. J Fish Res 33: 145-159.

$\mathrm{Xu}$ XY, Bin LL, Pan CZ, Ding AZ, Chen DS. 2014. Optimal reoperation of multi-reservoirs for integrated watershed management with multiple benefits. J Water 6: 796-812.

Zimmer KD, Hanson MA, Butler MG. 2003. Interspecies relationships, community structure, and factors influencing abundance of submerged macrophytes in Prairie wetlands. Wetlands 23: 717-728. 